\title{
STUDI FENOMENOLOGI: KECEMASAN KELUARGA SELAMA MENDAMPINGI KLIEN PADA FASE END OF LIFE DI RUMAH SAKIT PANTI WALUYA, SAWAHAN, MALANG
}

\author{
Yuldensia Avelina ${ }^{1}$, Retty Ratnawati ${ }^{2}$, Retno Lestari ${ }^{3}$ \\ ${ }^{1}$ Universitas Nusa Nipa Maumere NTT \\ ${ }^{2,3}$ Program Studi Magister Keperawatan Fakultas Kedokteran Universitas Brawijaya
}

\begin{abstract}
ABSTRAK
Respon emosional yang paling sering dialami keluarga selama mendampingi klien pada fase end of life adalah kecemasan, namun kecemasan yang dialami keluarga tersebut masih sering terabaikan oleh petugas kesehatan yang masih berfokus pada klien. Dimana dukungan dari petugas kesehatan sangat dibutuhkan oleh keluarga sebagai salah satu sumber kekuatan selama mendampingi klien. Kecemasan keluarga apabila tidak ditangani dapat menghambat keluarga selama mendampingi klien pada fase end of life. Tujuan dari penelitian ini adalah menggali makna dari pengalaman kecemasan keluarga selama mendampingi klien pada fase end of life. Penelitian ini menggunakan metode kualitatif dengan pendekatan fenomenologi interpretif. Pengambilan data dilakukan dengan wawancara mendalam pada 6 anggota keluarga yang mengalami kecemasan selama mendampingi klien pada fase end of life di rumah sakit. Hasil penelitian dianalisis dengan menggunakan IPA dari Smith. Penelitian ini menghasilkan 8 tema yaitu selalu berpikiran negatif sehingga hati tidak tenang, takut kehilangan orang yang dicintai, memastikan klien mendapatkan perawatan yang baik, menyemangati klien dengan berbagai cara, menampung pilihan lain selain pengobatan medis, disemangati oleh petugas kesehatan agar lebih tenang, adanya dukungan sikap empati dari anggota keluarga lainnya dan kompleksitas tanggung jawab keluarga dalam mendampingi dan membiayai pengobatan. Dapat disimpulkan bahwa kecemasan yang dialami keluarga selama mendampingi klien pada fase end of life merupakan perasaan cemas akan kehilangan orang yang dicintai. Oleh karena itu, berbagai upaya dilakukan keluarga meskipun adanya hambatan. Dukungan dari pihak lain menjadi sumber kekuatan bagi keluarga
\end{abstract}

Kata kunci: end of life, kecemasan, keluarga

\begin{abstract}
Emotional responses are most often experienced by the family for assisting patients on end of life phase is anxiety, but the anxiety experienced by these families is often overlooked by health professionals who are still focused on the patients. Wherein the support of health professionals is needed by the family as a source of strength for assisting patients. Family anxiety if left untreated can be a barrier for assisting patients in end of life phase. The purpose of this study is to explore the meaning of family anxieties experience for assisting patients on end of life phase. The study used a qualitative method with interpretive phenomenological design. Data were collected by indepth interviews on 6 family members who experience anxiety for assisting patients in the end phase of life in the hospital. The results were analyzed by using IPA from Smith. There were 8 themes is always minded negative so careful not quiet, afraid of losing a loved one, encouraging patients with a variety of ways, accommodating options other than medical treatment, ensuring patients receive good care, encouraged by health professionals to more quiet, empathetic support from other family members and the complexity of family responsibilities in supporting and financing the treatment. In conclusion the anxiety experienced by the family for assisting patients on end of life phase is feeling anxious about the loss of loved ones. Therefore, efforts were made families despite their obstacles. Support from other parties into a source of strength for the family.
\end{abstract}

Keyword: Anxiety, End of life phase, Family

Jurnal IImu Keperawatan, Vol:4, No.2 ; Korespondensi : Yuldensia Avelina. Universitas Nusa Nipa Maumere NTT. Email :nersyoully@gmail.com. No. Hp: 081233695883 


\section{PENDAHULUAN}

Fase end of life terjadi melalui suatu tahapan proses mulai dari penurunan kondisi fisik, psikososial dan spiritual klien hingga akhirnya kematian. Klien pada kondisi tersebut akan membutuhkan perawatan yang lebih intensif, waktu perawatan yang panjang dan obatobatan khusus yang mana biaya pengobatan yang dibutuhkan pun relatif mahal menyesuaikan pelayanan yang diberikan. Selain itu, klien yang dirawat juga memiliki tingkat ketergantungan yang tinggi (Fitria, 2010; Heidenreich, et.al., 2012).

Kompleksitas masalah yang dialami klien pada fase end of life, memberikan beban tersendiri pada keluarga yang terlibat langsung dalam perawatan karena klien membutuhkan perawatan total selama 24 jam. Apabila stresor ini berlangsung dalam waktu yang lama, maka dapat memunculkan respon emosional. Respon emosional yang paling sering ditemui adalah kecemasan (McAdam, et.al., 2012).

Kecemasan yang dialami oleh keluarga dapat disebabkan oleh beberapa faktor, diantaranya ketidakpastian baik medis, pelaksanaan tugas, psikososial dan spiritual. Pada faktor ketidakpastian medis dikarenakan selalu ada penambahan diagnosis dari dokter dan prognosis penyakit klien yang makin memburuk. Hal-hal yang terkait faktor ketidakpastian pelaksanaan tugas diantaranya pemenuhan kebutuhan klien, biaya perawatan dan perencanaan lainnya. Pada faktor ketidakpastian psikososial terkait apa yang akan terjadi dimasa depan. Sedangkan pada faktor ketidakpastian spiritual terkait makna hidup yakni sejauhmana keluarga menemukan makna hidup selama merawat anggota keluarganya. Faktor lainnya yang juga turut berperan menyebabkan kecemasan pada keluarga, yakni komunikasi yang kurang efektif antara keluarga dan perawat seperti dalam pemberian informasi yang dibutuhkan dan sikap empati yang masih dirasakan kurang oleh keluarga. Selain itu kesiapan keluarga dalam menerima kondisi klien seperti kesiapan menerima informasi terkait prognosis klien, kesiapan mental dalam menghadapi kondisi terburuk dan kesiapan dalam melaksanakan perubahan peran dan tanggung jawab (Henrikson \& Arestedt, 2013; Hebert, et.al., 2009).

Berdasarkan hasil studi pendahuluan pada keluarga yang mendampingi klien pada fase end of life yang dilakukan di salah satu ruangan kritis rumah sakit di Kota Malang pada tanggal 16 Maret 2016. Hasil dari studi pendahuluan yang dilakukan tersebut didapatkan bahwa kecemasan yang dialami oleh keluarga umumnya disebabkan belum adanya kemampuan untuk menerima kompleksitas penyakit yang dialami oleh klien 
saat ini. Selain itu, keluarga masih membutuhkan penyesuaian terhadap perubahan peran dan tanggung jawab dalam mengurus rumah tangga.

Kecemasan yang dialami keluarga dapat terlihat dari seringnya keluarga bertanya tentang penyakit yang dialami kepada perawat dan dokter meskipun sudah dijelaskan berulang kali. Selain itu, pikiran keluarga hanya ditujukan pada hal-hal yang dapat membuat klien mendapatkan perawatan yang baik dan dapat segera pulih, sehingga mereka sering mengabaikan kondisi kesehatan mereka sendiri. Dimana keluarga sudah merasa kelelahan, kurang tidur, sakit kepala bahkan penurunan nafsu makan. Hal tersebut tidak mereka ceritakan kepada anggota keluarga lainnya, yang mana apabila ditanya mereka mengatakan kondisinya baikbaik saja. Hal ini dilakukan keluarga agar dapat terus mendampingi klien. Pengalaman dalam merawat keluarga dengan kondisi yang sama tidak membuat keluarga dapat siap untuk menerima kondisi klien saat ini. Keluarga juga berusaha mencari solusi dan dukungan dari berbagai pihak dalam upaya mengurangi kecemasannya dan berharap klien memperoleh perawatan yang terbaik. Upaya tersebut seperti rutin berkonsultasi dengan dokter dan perawat di ruangan, mencari dukungan juga dari keluarga lainnya baik anak-anak, saudara serta kerabat terkait transportasi dan bantuan biaya perawatan serta hadir menjenguk klien setiap hari. Anggota keluarga lainnya juga turut saling bergantian dalam mendampingi klien di rumah sakit apabila keluarga sudah terlihat kelelahan.

Keluarga membutuhkan dukungan dalam merawat anggota keluarga yang berada pada fase end of life. Dukungan tersebut bisa berasal dari perawat berupa sikap empati dengan selalu mengunjungi klien dan keluarga. Selain itu perawat juga diharapkan dapat memberikan informasi yang dibutuhkan oleh keluarga. Hal ini penting untuk keluarga agar dapat menerima kondisi klien, mengurangi kecemasan dan berkomitmen dalam mendampingi klien. Pemberian dukungan juga diharapkan dari anggota keluarga lainnya. Dukungan yang diharapkan yakni turut mengunjungi selama di rumah sakit, menjadi tempat konsultasi, menyediakan transportasi, membantu tugastugas rumah tangga dan memberikan pengertian pada anak-anak. (McKiernan \& McCarthy, 2010; Mosher, et.al., 2013).

Beberapa faktor penghambat dalam memberikan perawatan kepada klien dapat juga meningkatkan kecemasan pada keluarga. Hal-hal yang dapat menghambat peran keluarga tersebut diantaranya perubahan peran dan tanggung jawab serta akses rumah 
ke rumah sakit turut menjadi faktor penghambat bagi keluarga dalam merawat klien pada kondisi end of life (Brereton, et.al., 2011; Hudson, et.al., 2012).

Berdasarkan fenomena yang terjadi diatas, mendampingi orang yang dicintai dalam fase end of life di rumah sakit, menimbulkan beban tersendiri bagi keluarga karena membawa banyak perubahan dalam sistem keluarga, baik peran, status kesehatan keluarga dan tanggung jawab keuangan. Segala perubahan inilah memunculkan kecemasan. Keluarga berupaya untuk mengatasi kecemasannya walaupun mengalami kendala. Penelitian terkait pengalaman keluarga selama mendampingi klien pada kondisi end of life masih membutuhkan penelitian lanjutan.

Tujuan dilakukan penelitian ini yakni menggali makna dari pengalaman kecemasan keluarga selama mendampingi klien pada fase end of life.

\section{METODE}

Metode yang digunakan dalam penelitian ini adalah metode kualitatif dengan pendekatan fenomenologi interpretif (Afiyanti \& Rachmawati, 2014).

Penelitian ini dilakukan di Ruang Kritis Sakit Panti Waluya, Sawahan, Malang pada pertengahan Mei sampai dengan awal Juni 2016. Enam partisipan terlibat dalam penelitian ini. Keenam partisipan tersebut dipilih menggunakan teknik purposive sampling yakni melakukan seleksi kepada keluarga yang mendampingi klien pada fase end of life yang telah memenuhi kriteria inklusi yang telah ditetapkan oleh peneliti dan peneliti tidak menemukan informasi baru atau telah tercapai saturasi data. Saturasi data tercapai pada partisipan keenam.

Kriteria inklusi tersebut antara lain (1) memiliki anggota keluarga yang masuk pada fase end of life; (2) anggota keluarga yang dipilih adalah pasangan, orangtua, anak, saudara yang sehari-hari mendampingi klien pada fase end of life; (3) anggota keluarga yang telah teridentifikasi mengalami kecemasan sedang melalui keluhan yang disampaikan serta respon yang ditunjukkannya; (4) mengikuti perkembangan klien sejak sebelum fase end of life; (5) bersedia ikut sebagai partisipan dengan menandatangani surat kesediaan menjadi partisipan; (6) dapat menceritakan pengalamannya dengan baik/kooperatif.

Proses pemilihan partisipan dilaksanakan setelah mendapatkan kelayakan etik dari komite etik dan ijin penelitian dari rumah sakit. Dalam proses identifikasi partisipan, peneliti dibantu oleh kepala ruangan dan perawat yang bertugas di ruangan tersebut.

Sebagian besar partisipan dalam penelitian ini berjenis kelamin perempuan dan hanya 1 
partisipan berjenis kelamin laki-laki. Pada umumnya partisipan merupakan anak dan pasangan dalam hubungan dengan klien yang sedang dirawat sisanya adalah orangtua dan saudara. Keseluruhan partisipan telah mendampingi klien selama kurang lebih 2-4 hari sejak klien masuk rumah sakit. Partisipan tersebut semuanya mengalami kecemasan sedang yang ditunjukkan dari keluhan yang mengarah kepada kecemasan sedang saat wawancara. Namun, partisipan tersebut masih dapat menerima arahan dari pihak lain baik dari anggota kelaurga lainnya dan petugas kesehatan. Selain itu, partisipan tampak kooperatif dan dapat menceritakan segala kecemasana yang dirasakannya. Setiap partisipan dilakukan wawancara mendalam selama kurang lebih 30-60 menit.

Pengambilan data dilakukan menggunakan teknik wawancara mendalam (indepth interview) dan observasi. Indepth interview dilakukan dengan menggunakan panduan wawancara yang sudah disiapkan. Observasi dilakukan dengan mengamati ekspresi partisipan seperti ekspresi wajah, bahasa tubuh dan berbagai reaksi partisipan ketika berbicara yang terkait pernyataan partisipan yang diberikan serta situasi lingkungan selama proses indepth interview tersebut. Selanjutnya akan ditulis kedalam catatan lapangan (field notes).
Instrumen utama dalam penelitian kualitatif adalah peneliti sendiri. Peneliti sebagai instrument penelitian yang utama dibantu juga dengan instrumen pengumpulan data lainnya yakni pedoman wawancara mendalam, catatan lapangan dan handphone sebagai alat perekam suara.

Proses pengumpulan data meliputi 2 tahap yakni tahap prosedur penelitian yang berkaitan dengan pengurusan ijin administrasi penelitian meliputi ijin penelitian ke rumah sakit dan kelayakan etik penelitian. Tahap berikutnya yakni strategi pengumpulan data. Dimana proses pengumpulan data dimulai setelah peneliti memperoleh kelayakan etik dari komite etik penelitian dan ijin penelitian dari rumah sakit..

Analisa data dalam penelitian ini menggunakan interpretive phenomenological analysis (IPA) dari Smith, et.al. (2009).

\section{HASIL}

Penelitian ini menghasilkan sebuah tema besar yaitu semua karena cinta keluarga kepada klien. Tema besar ini akan dijabarkan kedalam delapan tema, sebagai berikut:

\section{Tema 1: Selalu berpikiran negatif sehingga} hati tidak tenang

Pikiran negatif merupakan pola atau cara berpikir yang lebih condong pada sisi-sisi negatif dibanding sisi-sisi positifnya. Pola pikir 
ini bisa tampak dari keyakinan atau pandangan yang terucap tentang tanggapan penyakit klien sebagai sesuatu yang berbahaya, perkembangan kondisi klien yang makin memburuk dan adanya perubahan kondisi yang begitu cepat dari sebelumnya. Selain itu, pola pikir ini dapat tampak dari cara partisipan bersikap yakni dengan mempertanyakan keselamatan klien. Tema ini disusun oleh 3 sub tema yaitu perkiraan kondisi penyakit yang makin memburuk, pikiran yang tidak tenang dan perasaan cemas akan kehilangan orang yang dicintai.

Sub tema pertama yaitu perkiraan kondisi penyakit yang makin memburuk diungkapkan oleh partisipan dengan perubahan kondisi klien yang mendadak tidak sadar, diagnosis medis yang terus berubah dan klien tidak dapat terselamatkan. Hal tersebut didukung oleh pernyataan partisipan sebagai berikut:

“...hari senin pagi langsung masuk..tapi ibu udah enggak sadar.. matanya kayak terbalik gitu (tidak dapat membuka mata)..sampe sekarang belum sadar mbak..masih kritis" (p3).

“..saya pikir bahwa struk itu penyakit yang fatal..membahayakan..pokok ee mematikan karna kalo dengar-dengar orang yang struk meninggal..itu yang buat saya cemas..takut" (p6).

Sub tema kedua yaitu pikiran yang tidak tenang diungkapkan oleh partisipan dengan memikirkan seperti apa kondisi klien kedepannya dan mempertanyakan masa depan tanpa orang yang dicintai. Memikirkan seperti apa kondisi klien kedepannya. Hal ini membuat partisipan tidak dapat mengambil keputusan jika dihadapkan pada pilihan alternatif pengobatan karena apabila salah memilih dapat mengancam keselamatan klien. Bingung merupakan satu ungkapan yang dapat menggambarkan situasi tersebut, seperti diungkapkan oleh partisipan berikut ini:

“..yang pertama katanya nanti dioperasi otaknya..katanya untuk keluarkan perdarahan yang buat tersumbat di otak..kalo enggak pake alternatip kedua yakni diobati biasa seperti sekarang ini mbak..saya bingung..makin cemas saya" (p3).

Mempertanyakan masa depan tanpa orang yang dicintai, yang didukung oleh pernyataan partisipan berikut ini:

"..mana lihat anak-anaknya saya jadi makin sedih..kasian mereka juga masih pada sekolah..ada yang nomer tiga lagi ada ujian..bagaimana dengan hari-hari kedepannya..bagaimana dengan anakanaknya ini" (p2).

Sub tema ketiga perasaan cemas akan kehilangan orang yang dicintai. Perasaan cemas akan kehilangan orang yang dicintai diungkapkan keluarga dengan adanya 
kekuatiran akan kondisi klien yang makin memburuk dan merasa akan kehilangan orang yang dicintai. Respon setiap keluarga terhadap kecemasannya berbeda-berbeda yakni tidak dapat makan, tidak dapat tidur dan sulit berpikir. Hal ini diungkapkan oleh pernyataan partisipan berikut:

"..saya kuatir dan takut banget kalo-kalo terjadi sesuatu..kasihan anaknya kedua masih kecil..masih umur empat bulan" (p1).

\section{Tema 2: Takut kehilangan orang yang dicintai}

Perasaan takut kehilangan orang yang dicintai merupakan perasaan tidak ingin ditinggalkan orang yang dicintai. Tema ini disusun oleh 1 sub tema yakni belum siap ditinggalkan orang yang dicintai.

Sub tema belum siap ditinggalkan orang yang dicintai mempunyai arti adanya ketidaksiapan mental untuk kehilangan karena masih ingin bersama klien. Belum siap ditinggalkan orang yang dicintai diungkapkan partisipan sebagai perasaan belum siap terima kondisi terburuk dan pengalaman pernah kehilangan keluarga terdekat. Hal ini didikung oleh pernyataan berikut:

“..kaget, sedih, kuatir, takut soalnya slama ini sehat-sehat saja..kolesterolnya baik, asam uratnya normal, tensi baik, gula baik, jantungnya juga sehat" (p6).

"...setahun yang lalu bapak saya $\underline{\text { meninggal juga gara-gara seperti ini...jadi }}$ ketika ibu dikatakan kena struk juga sok saya..." (p4).

\section{Tema 3: Memastikan klien mendapatkan} perawatan yang baik

Memastikan klien mendapatkan perawatan yang baik merupakan salah satu upaya partisipan dalam mengatasi kecemasan yang dialaminya. Tema ini disusun oleh 1 sub tema yakni keinginan untuk selalu mengikuti perkembangan kondisi klien.

Sub tema keinginan untuk selalu mengikuti perkembangan kondisi klien diungkapkan partisipan dengan selalu mencari informasi tentang klien dan ingin terus berada di samping klien. Hal tersebut didukung oleh pernyataan partisipan berikut ini:

"trus saya tanya mbak sama dokternya..apa itu struk..yah dokternya ngejelasin sama saya..dokter juga bilang kondisi ibu saya ini sudah berat" (p3).

\section{Tema 4: Menyemangati klien dengan} berbagai cara

Menyemangati klien dengan berbagai cara berarti bahwa partisipan senantiasa memberikan energi semangat dengan harapan klien akan merasa tidak sendiri dan mempunyai kekuatan untuk melawan penyakitnya. Tema ini disusun oleh 1 sub tema yakni adanya perhatian terhadap klien. 
Sub tema adanya perhatian terhadap klien mempunyai arti adanya sikap empati dari keluarga yang ditunjukkan dengan mengajak klien berkomunikasi dan adanya keinginan untuk tetap bersama klien. Hal tersebut didukung oleh pernyataan partisipan berikut ini:

“...saya juga bacakan doa-doa ke telinga ibu...walaupun gak ada respon dari wajah ibu tapi saya ngerasain jari-jari tangannya yang saya genggam terasa bergerak" (p4).

\section{Tema 5: Menampung pilihan lain selain} pengobatan medis

Menampung pilihan lain selain pengobatan medis mempunyai arti bahwa partisipan menerima usul dan saran tentang alternatif pengobatan dari anggota keluarga lainnya tetapi partisipan belum dapat melaksanakan apa yang diusulkan tersebut. Hal ini dikarenakan partisipan masih berfokus pada pengobatan medis. Tema ini memiliki 1 sub tema yaitu adanya perencanaan pilihan pengobatan.

Sub tema adanya perencanaan pilihan pengobatan diungkapkan oleh partisipan sebagai alternatif pemecahan masalah yang ditawarkan oleh anggota keluarga lainnya seperti pemberian obat lain, pengobatan secara religi dan adanya pengobatan alternatif. Hal tersebut didukung oleh pernyataan partisipan berikut:

"..dari ade-ade ibu tuh banyak yang ngusul (mengusulkan) pake obat herbal dikasih kalo ibu sudah sadar" (p4).

“..keluarga juga ngusulkan buat panggil kiai untuk doain ibu" (p4).

\section{Tema 6: Disemangati oleh petugas kesehatan} agar lebih tenang

Disemangati oleh petugas kesehatan agar lebih tenang. Petugas kesehatan dalam hal ini adalah dokter dan perawat mempunyai peranan penting dalam memberikan dukungan kepada partisipan selama mendampingi klien pada fase end of life. Bentuk dukungan yang diberikan kepada partisipan berbeda sesuai dengan kebutuhan partisipan. Tema ini disusun oleh 1 sub tema yakni adanya perhatian dari petugas kesehatan.

Sub tema adanya perhatian dari petugas kesehatan mempunyai arti adanya sikap empati dari dokter dan perawat melalui dukungan peneguhan dan juga dukungan semangat. Hal tersebut diungkapkan oleh pernyataan partisipan berikut ini:

“...dokternya bagus banget dan baik..kasih kekuatan juga..perawat disini..selalu kasih penguatan supaya sabar dan kuat untuk menghadapi ini" (p5). 
Tema 7: Adanya dukungan sikap empati dari anggota keluarga lainnya

Adanya dukungan sikap empati dari anggota keluarga lainnya mempunyai arti adanya kemampuan anggota keluarga lainnya untuk mampu memahami perasaan dan pikiran partisipan. Tema ini disusun oleh 1 sub tema yakni perhatian dari anggota keluarga lainnya.

Sub tema perhatian dari anggota keluarga lainnya diungkapkan oleh partisipan dengan adanya dukungan semangat, dukungan ekonomi, dukungan dalam peran mendampingi, dukungan dalam membantu tugas-tugas rumah tangga dan transportasi. Hal tersebut diungkapkan oleh pernyataan partisipan berikut ini:

"anak dan suami saya tetep kasi
semangat" (p3).

“..yang biasa gantian jaga saya dan ade

saya nomer 2 sama suaminya" (p4).

Tema 8: Kompleksitas tanggung jawab keluarga dalam mendampingi dan membiayai pengobatan

Kompleksitas tanggung jawab keluarga dalam mendampingi dan membiayai pengobatan mempunyai arti bahwa partisipan dalam mendampingi juga mengalami keterbatasan atau kesulitan untuk menanggung segala sesuatu seperti dalam menjalankan tambahan tanggung jawab dan memenuhi biaya pengobatan. Tema ini disusun oleh 2 sub tema yakni kesulitan melaksanakan tambahan tanggung jawab dan tidak mampu penuhi biaya pengobatan.

Sub tema kesulitan melaksanakan tambahan tanggung jawab diungkapkan oleh partisipan dengan tanggung jawabnya banyak. Hal tersebut didukung oleh pernyataan partisipan sebagai berikut:

“..mana ngurus rumah seperti masakin buat anak-anak dan suami..ngatur rumah walau segitunya saja..mana ngontrol usaha kami..walaupun ada suami tapi yang biasa ngurusin usaha kami itu saya..mana minta bantuan ke keluarga" (p3).

Sub tema tidak mampu penuhi biaya pengobatan diungkapkan oleh partisipan dengan merasa kesulitan untuk menjangkau biaya pengobatan dan keluhan mahalnya biaya pengobatan. Kesulitan untuk menjangkau biaya pengobatan dikarenakan biaya pengobatan yang diperkirakan akan meningkat sedangkan keluhan mahalnya biaya pengobatan diungkapkan oleh partisipan dengan biaya pengobatan terlalu besar dan biaya pengobatan mahal. Hal tersebut diungkapkan oleh partisipan sebagai berikut:

"kalo saya pribadi juga merasa kesulitan..sebetulnya kalo dibilang besar yah besar mbak soalnya enggak pake BPJS..apalagi kalo semakin lama dirawat 
juga makin besar biayanya..trus ada

alternatip operasi..itu cukup berat mbak" (p3).

\section{PEMBAHASAN}

Kecemasan merupakan respon emosional yang paling sering ditemui pada keluarga yang mendampingi klien selama fase end of life. Alasan munculnya kecemasan pada keluarga dalam penelitian ini yakni selalu berpikiran negatif tentang kondisi klien. Pikiran negatif muncul saat keluarga mendengar diagnosis medis yang terus berubah, melihat perubahan kondisi yang berbeda dari sebelumnya dan mempunyai anggapan bahwa penyakit yang dialami klien dapat membuat klien tersebut tidak dapat terselamatkan. Menurut Hebert, et.al. (2009) dalam penelitiannya mengungkapkan bahwa adanya diagnosis medis yang semakin kompleks dan prognosis penyakit klien yang semakin memburuk menjadi penyebab kecemasan yang dialami keluarga selama mendampingi klien pada fase end of life. Li, et.al. (2013) juga menyatakan bahwa pada umumnya kecemasan keluarga akan meningkat seiring dengan semakin memburuknya kondisi klien.

Peningkatan kecemasan keluarga dapat berdampak pada kondisi fisiknya seperti kurang tidur, kelelahan, sakit kepala hingga penurunan nafsu makan.
Perasaan keluarga tentang kecemasan yang dialaminya selama mendampingi klien pada fase end of life yakni takut kehilangan orang yang dicintai. Keluarga pada umumnya masih ingin bersama klien yang ditunjukkan dengan perasaan belum siap menerima kondisi terburuk. Hebert, et.al. (2009) dan Henrikson \& Arestedt (2013) mengungkapkan bahwa perasaan belum siap menerima kondisi terburuk sebagai bentuk kurangnya kesiapan mental keluarga dalam menghadapi situasi terburuk. Disisi lain, keluarga belum siap menerima kondisi terburuk dapat terjadi karena keluarga pernah kehilangan anggota keluarga terdekat. Hebert, et.al. (2009) juga menyatakan hal yang sama bahwa pernah mengalami kehilangan tidak selalu cukup untuk mempersiapkan keluarga dalam menerima kondisi klien termasuk penerimaan akan kematian nantinya.

Keluarga selama mendampingi klien pada fase end of life akan mengusahakan yang terbaik agar klien bisa pulih. Upaya yang dilakukan keluarga diantaranya dengan memastikan bahwa klien mendapatkan perawatan yang baik, yang dilakukan dengan selalu mencari informasi tentang penyakit klien, perawatan dan pengobatan juga kesembuhan klien kepada dokter dan perawat. Selain kepada perawat dan dokter, keluarga juga mencari informasi kepada teman. Stajduhar, et. al, 
(2013) mengatakan bahwa keluarga dalam mengatasi kecemasannya dapat menggunakan cara mencari informasi yang dibutuhkan baik dengan membaca buku-buku tentang penyakit yang sedang dialami anggota keluarga, bertanya pada tim professional kesehatan dan dapat berbagi pengalaman dengan teman-teman atau kerabat lainnya yang mempunyai masalah yang sama. Upaya berikutnya yang dilakukan oleh keluarga adalah dengan menyemangati klien yakni dengan menunggu klien di ruang tunggu keluarga setelah jam berkunjung selesai. Hal ini dikarenakan keluarga meyakini bahwa walaupun klien tidak sadar tetapi masih bisa mendengar apa yang disampaikan dengan harapan agar klien dapat lebih kuat untuk melawan penyakitnya. Mosher, et.al. (2013) juga menyatakan demikian bahwa mendampingi di samping tempat tidur dan berbicara kata-kata penghiburan dapat memberikan dukungan spiritual bagi klien, agar klien merasa tidak sendirian dalam menghadapi penyakitnya. Upaya terakhir yang dapat dilakukan oleh keluarga yakni dengan menampung pilihan lain selain pengobatan medis yang disampaikan oleh anggota keluarga lainnya, meliputi pemberian jamu, obat herbal, pengobatan secara religi dan pengobatan alternatif. Keluarga mempunyai alasan tersendiri untuk menampung semua usulan untuk pilihan pengobatan lain selain pengobatan medis yakni dapat membantu dalam proses penyembuhan klien.

Dukungan dari pihak lain sangat dibutuhkan oleh keluarga untuk mengurangi kecemasan yang dialaminya walaupun sekecil apapun bentuknya. Pihak lain yang turut memberikan dukungan pada keluarga yakni anggota keluarga lainnya dan para petugas kesehatan yang menangani klien selama dirawat.

Dukungan dari petugas kesehatan, dalam hal ini dokter dan perawat memberikan kontribusi yang cukup besar karena dapat memberikan jaminan akan keselamatan klien. Bentuk dukungan tersebut berupa disemangati oleh petugas kesehatan yang ditunjukkan dengan mendengarkan keluhan, memberikan penguatan serta sebagai tempat konsultasi dalam upaya mencari solusi untuk penyembuhan klien. Dalam berbagai hasil penelitian ditemukan bahwa dukungan dari para petugas kesehatan dalam pemberian informasi yang dibutuhkan maupun dukungan perhatian lainnya masih dirasakan kurang oleh keluarga (Coombs, 2015; Henrikson \& Arestedt, 2013; McKiernan \& McCarthy, 2010).

Kondisi ini berbeda dengan yang dialami keluarga selama penelitian, dimana keluarga sudah merasakan cukup didukung oleh petugas kesehatan dalam pemberian informasi maupun semangat. Namun disisi 
lain, berdasarkan apa yang disampaikan oleh keluarga bahwa memang yang lebih memberikan perhatian adalah dokter. Dimana dokter yang lebih banyak diajak konsultasi tentang perkembangan klien dan lebih banyak pula memberikan peneguhan jika dibandingkan dengan yang diberikan oleh perawat.

Dukungan sikap empati dari anggota keluarga lainnya juga sangat diharapkan keluarga selama mendampingi klien pada fase end of life. Bentuk empati yang ditunjukkan yakni melalui perhatian seperti sikap saling pengertian, turut membantu biaya pengobatan, ikut menjaga klien di rumah sakit, mengantar dan menjemput anggota keluarga yang akan gantian menjaga, mengurus anak dari klien yang sedang dirawat, membersihkan rumah, memasak dan sebagainya. Dalam berbagai hasil penelitian diungkapkan bahwa pemberian dukungan dari anggota keluarga lainnya juga sangat diharapkan oleh keluarga selama mendampingi klien pada fase end of life. Dukungan yang diharapkan yakni turut mengunjungi selama di rumah sakit, sebagai tempat konsultasi, menyediakan transportasi, membantu tugas-tugas rumah tangga dan memberikan pengertian kepada anak-anak. Dengan demikan anggota keluarga lainnya sudah menunjukkan empatinya kepada keluarga yang mendampingi klien pada fase end of life (McKiernan \& McCarthy, 2010; Mosher, et.al., 2013).

Hambatan yang dialami keluarga selama mendampingi klien pada fase end of life yakni kompleksitas tanggung jawab keluarga selama mendampingi dan membiayai pengobatan. Tanggung jawab yang harus dilaksanakan oleh keluarga selain mendampingi klien di rumah sakit juga harus mengatur banyak hal, seperti mengumpulkan saudara, mengurus rumah tangganya sendiri dan menggantikan peran dari klien tersebut. Dengan adanya banyak tanggung jawab yang harus dilaksanakan membuat keluarga sudah mulai merasakan kelelahan dan kondisi fisiknya sudah mulai menurun. Menurut Efendy, et.al. (2014) dalam penelitiannya mengungkapkan bahwa hambatan yang dialami keluarga selama mendampingi klien pada fase end of life seperti tanggung jawab terhadap pekerjaan rumah tangga. Hal ini menyebabkan keluarga harus mengatur ulang tugas dan kewajiban yang biasa mereka lakukan, misalnya kegiatan rumah tangga sendiri, selain itu juga merawat orang lain yang bergantung pada mereka seperti anak-anak. Kesulitan lainnya yang menjadi hambatan bagi keluarga yakni tidak mampu dalam memenuhi biaya pengobatan. Keluarga cukup dilema karena disatu sisi mereka ingin agar klien mendapatkan pengobatan dan perawatan yang baik tetapi disisi lainnya mereka harus dihadapkan 
dengan biaya pengobatan yang dirasakan sangat mahal. Perubahan kondisi ini dirasakan keluarga sebagai sebuah hambatan selama mendampingi klien.

\section{KESIMPULAN}

Keluarga yang mendampingi klien pada fase end of life akan mengalami kecemasan yang disebabkan selalu berpikiran negatif tentang kondisi klien yang dimulai saat mendengar diagnosis medis yang terus berubah, melihat perubahan kondisi yang berbeda dari sebelumnya dan mempunyai anggapan bahwa penyakit yang dialami klien dapat membuat klien tersebut tidak dapat terselamatkan. Selama mendampingi klien dan melihat perubahan kondisi klien yang tidak kunjung membaik, membuat keluarga memiliki perasaan takut kehilangan orang yang dicintai. Oleh karena itu, keluarga berupaya untuk memastikan bahwa klien mendapat perawatan yang baik, menyemangati klien dengan berbagai cara dan menampung pilihan lain selain pengobatan medis.

Ditengah rasa cemas yang dirasakan, keluarga butuh disemangati oleh petugas kesehatan dan adanya dukungan sikap empati dari

\section{DAFTAR PUSTAKA}

Afiyanti, Y., \& Rachmawati, I. N. (2014). Metodologi penelitian kualitatif dalam anggota keluarga lainnya. Keluarga juga mengalami hambatan selama mendampingi klien yakni adanya kompleksitas tanggung jawab keluarga dalam mendampingi dan membiayai pengobatan.

Saran yang dapat diberikan dari penelitian ini ditujukan pada keluarga, perawat dan peneliti selanjutnya. Bagi keluarga, peneliti menyarankan agar dapat menggunakan support system yang sudah ada baik yang berasal dari anggota keluarga lainnya maupun petugas kesehatan sebagai sumber kekuatan untuk mengatasi kecemasan.

Bagi perawat, hendaknya memberikan asuhan keperawatan pada kondisi end of life tidak hanya kepada klien tetapi juga pada keluarga sebagai support system dari klien sendiri.

Sedangkan bagi peneliti selanjutnya dapat menggali pengalaman psikologis lainnya dari keluarga dalam mendampingi klien pada fase end of life. Selain itu juga dapat menggali pengalaman perawat sebagai salah satu support system keluarga dalam memberikan intervensi psikososial pada keluarga yang mengalami kecemasan.

riset keperawatan. Jakarta: PT Raja Grafindo Persada.

Bevans, M. F., \& Sternberg, E. M. (2012). 
Caregiving burden, stress and health effects among family caregivers of adult cancer patients. JAMA, 307 (4), 398-403. Brereton, L., Gardiner, C., Gotf, M., Ingleton, C., Barners, S., \& Carroll, C. (2011). The hospital enviroment for end of life care of older adults and their families: As integrative review. Journal of advanced nursing, 1-13.

Coombs, M. (2015). A scoping review of family experience and need during end of life care in intensive care. John wiley \& sons Ltd , 24-35.

Effendy, C., Dassen, M. V., Setiyarini, S., Kristanti, M. S., Tejawinata, S., Vissers, K., et al. (2014). Family caregivers involvement in caring for a hospitalized patient with cancer and their quality of life in a country with strong family bonds. Psycho-oncology, 1-7.

Fitria, C. N. (2010). Palliative care pada penderita penyakit terminal. GASTER, 7 (1), 527-535.

Hebert, R. S., Schulz, R., Copeland, V. C., \& Arnold, R. M. (2009). Preparing family caregivers for death and bereavement. Journal of pain \& symptom management, 37 (1), 3-12.

Heidenreich, M. T., Koo, F. K., \& White, K. (2012). The experience of Chinese immigrant woman in caring for a terminally ill family member in Australia. Elsevier, Ltd., 21 (2012), 275-285.

Henrikson, A., \& Arestedt, K. (2013). Exploring factors and caregivers outcomes associated with feelings of preparedness for caregiving in family caregivers in palliative care. Palliative Medicine, 27 (7), 639-646

Hudson, P., Remedios, C., Zordan, R., Thomas, K., Clifton, D., Crewdson, M., et al. (2012). Guidelines for the psychosocial and bereavement support of family caregivers of palliative care patients. Journal of Palliative Medicine, 15 (6), 696-702.

Li, Q. P., Loke, A. Y., \& Mak, Y. W. (2013). Spouse's experience of caregiving for cancer patients. International Nursing Review , 60 (1), 178-187.

McAdam, J., Fontaine, D. K., White, D. B., Dracup, K. A., \& Puntillo, K. A. (2012). Psychological symptoms of family members of high-risk intensive care unit patients. American Journal of Critical Care, 21 (6), 386-393.

McKiernan, M., \& McCarthy. (2010). Family members' lived experience in the intensive care unit. Elsevier, 26 (2010), $254-261$

Mosher, C. E., Jaynes, H. A., Hanna, N., \& Ostroff, J. S. (2013). Distress family 
caregivers of lung cancer patients. Smith, J., Flowers, P., \& Larkin, M. (2009). Support Care Cancer, 21 (2), 431-437. Interpretative Phenomenological

Saunders, D. C. (2008). End of life strategy. Analysis. London: SAGE Publication Ltd. London: COI for The Department of Health.

Stajduhar, K. I., Outcalt, L., \& Funk, L. (2013). Family caregiver learning. Palliative

Setiawan, E. (2016). Kamus Besar Bahasa Medicine, 27 (7), 657-664.

Indonesia Online. KEMDIKBUD, Badan Pengembangan \& Pembinaan Bahasa. http://www.kbbi.web.id.

Streubert, H. J., \& Carpenter, D. R. (2011). Qualitative research in nursing (Fifth ed.). Philadelphia: Lippincott Williams \& Wilkins. 